\title{
RESEARCH
}

\section{Stimulation of growth hormone by kisspeptin antagonists in ewes}

\author{
J T Smith', A Roseweir2,3, M Millar4, I J Clarke5 and R P Millar6,7 \\ 1School of Human Sciences, The University of Western Australia, Perth, Western Australia, Australia \\ ${ }^{2}$ Academic Unit of Surgery, School of Medicine, University of Glasgow, Royal Infirmary, Glasgow, UK \\ 3Unit of Experimental Therapeutics, Institute of Cancer Sciences, University of Glasgow Glasgow, UK \\ ${ }^{4}$ Queen's Medical Research Institute, University of Edinburgh, Edinburgh, UK \\ ${ }^{5}$ Department of Physiology, Monash University, Clayton, Victoria, Australia \\ ${ }^{6}$ Centre for Neuroendocrinology, Department of Immunology and Physiology, University of Pretoria, Pretoria, South Africa \\ ${ }^{7}$ Institute for Infectious Diseases and Molecular Medicine, University of Cape Town, Cape Town, South Africa \\ Correspondence should be addressed to R P Millar: robertpetermillar@gmail.com
}

\begin{abstract}
Kisspeptin signalling is indispensable for fertility, stimulating gonadotropin-releasing hormone $(\mathrm{GnRH})$ secretion and mediating gonadal steroid feedback on GnRH neurons. Moreover, kisspeptin neurons have been implicated in other non-reproductive neuroendocrine roles. Kisspeptin appears to also regulate growth hormone secretion but much of the data appear contradictory. We sought to clarify a potential role of kisspeptin in growth hormone $(\mathrm{GH})$ regulation by examining the effect of kisspeptin antagonists on GH secretion in ewes under various physiological conditions. Our data show clear and robust increases in $\mathrm{GH}$ secretion following lateral ventricle or third ventricle infusion of kisspeptin antagonists $p-234$ and $p-271$ in either ovariectomized or anestrous ewes. Central infusion of kisspeptin-10 had no effect on GH secretion. To determine the level at which kisspeptin may influence GH secretion, we examined expression of the cognate kisspeptin receptor, GPR54, in pituitary cells and showed by immunocytochemistry that the majority of somatotropes express GPR54 while expression was largely negative in other pituitary cells. Overall, we have demonstrated that blocking kisspeptin signalling by antagonists stimulates $\mathrm{GH}$ secretion in ewes and that this is likely mediated by inhibiting endogenous kisspeptin activation of GPR54 expressed on somatotropes. The findings suggest that endogenous kisspeptin inhibits GH secretion through GPR54 expressed on somatotropes.
\end{abstract}

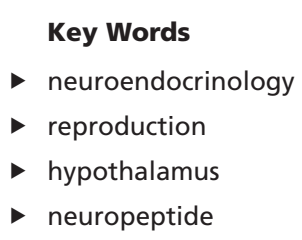

Journal of Endocrinology (2018) 237, 165-173

\section{Introduction}

Kisspeptin and its cognate receptor GPR54 are now well accepted as a critical component of central nervous system regulation of GnRH neuron control of reproductive hormones (de Roux et al. 2003, Seminara et al. 2003, Topaloglu et al. 2012). Kisspeptin neuron activity is essential for the stimulation of GnRH secretion (Gottsch et al. 2004, Han et al. 2005) and mediates both negative and positive feedback regulation by gonadal steroid hormones onto GnRH neurons (Smith 2013) and kisspeptin signalling is required for the onset of puberty (Han et al. 2005).

Leptin and products of metabolism also impact on kisspeptin neuron function and kisspeptin neurons are hypothesized to be 'whole body sensors' linking physiological status to reproduction (Pineda et al. 2010a). Growth hormone (GH) plays a role in normal reproductive 
function (Hull \& Harvey 2001, 2002) and in metabolic regulation. A substantial number of studies have now reported effects of kisspeptin on GH secretion in various species, under different physiological conditions, using peripheral or central administration, and by examining direct effects on pituitary cells in culture (GutierrezPascual et al. 2007, Kadokawa et al. 2007, 2008, Lents et al. 2008, Whitlock et al. 2008, 2010, Foradori et al. 2017). Kisspeptin is a member of the large family of RFamide peptides that target an equally large family of cognate receptors (Dockray 2004). Consequently, doses and mode of administration of kisspeptin might have effects that are not mediated via the GPR54 cognate receptor but result from activation of other GPCRs (Oishi et al. 2011), which may contribute to contradictory reports of kisspeptin effects on $\mathrm{GH}$.

In an attempt to clarify effects of kisspeptin on $\mathrm{GH}$, we have studied the effects of kisspeptin antagonists on GH secretion in ewes under various physiological conditions. Our data suggest that GH is under endogenous kisspeptin inhibition, which is relieved by kisspeptin antagonist treatment, resulting in an elevation of GH.

\section{Materials and methods}

\section{Animals and peptides}

All experimental procedures were conducted under a protocol approved by the Monash School of Biomedical Sciences Animal Ethics Committee. Adult Corriedale ewes were housed under natural lighting. Kisspeptin antagonist (peptide-234 and peptide-271) were synthesized by EZBiolab Inc. (Carmel, IN, USA).

The peptide sequence of peptide-234 is ac-(D-A) NWNGFG(D-W)RF-NH2 (Roseweir etal. 2009). Peptide-271 is the same sequence as peptide-234 with the addition of a seven amino acid cationic cell-penetrating peptide penetratin RRMKWKK extension at the NH2 terminus of peptide-234. This peptide was shown in vitro and in vivo in rats, mice, sheep and monkeys to be an effective kisspeptin antagonist (Roseweir et al. 2009, Millar et al. 2010, Pineda et al. 2010b, Smith et al. 2011, Guerriero et al. 2012, De Bond et al. 2013, Roseweir \& Millar 2013, Albers-Wolthers et al. 2017).

Kisspeptin peptide YNWNSFGLRY-NH2 corresponding to the murine C-terminal KISS1 decapeptide was obtained from Phoenix Pharmaceuticals Ltd. (Belmont, CA, USA). This sequence is identical to the C-terminal sequence of ovine kisspeptin (GenBank accession No. DQ059506).
Effect of kisspeptin antagonists on GH secretion

in ewes

\section{Experiment 1: effect of third ventricular infusion of peptide 234 on $\mathrm{GH}$ in ovariectomized ewes}

Experiments were performed as described previously (Roseweir et al. 2009). Animals were bilaterally ovariectomized (OVX) at least one month before any experimental manipulations. Permanent indwelling third cerebral ventricular $(3 \mathrm{~V})$ cannulae were implanted in a subsequent surgical procedure as described previously (Barker-Gibb et al. 1995). Approximately 2 weeks after $3 \mathrm{~V}$ surgery, one external jugular vein was cannulated for blood sampling and animals housed in single pens; cannulae were kept patent with heparinized saline. Ewes were assigned to treatment groups ( $n=4$ per group); peptide 234 (diluted in aCSF; $150 \mathrm{mM} \mathrm{NaCI}, 1.2 \mathrm{mM} \mathrm{CaCI} 2,1 \mathrm{mM}$ $\mathrm{MgCI} 2,2.8 \mathrm{mM} \mathrm{KCI}$ ) or control (aCSF only). The following day, infusion lines were connected to $3 \mathrm{~V}$ cannulae, and blood sampling commenced at 07:00 h. Samples were collected every $10 \mathrm{~min}$. After $3 \mathrm{~h}$ of sampling, peptide 234 (or control) was infused into the $3 \mathrm{~V}$ at a dose of $40 \mu \mathrm{g} / \mathrm{h}$ for $1 \mathrm{~h}$, with an initial dose of $10 \mu \mathrm{g}$. Both peptide 234 and vehicle were infused at $200 \mu \mathrm{L} / \mathrm{h}$ using Graseby MS16A infusion pumps (Smith Medical Australasia, Bella Vista, NSW, Australia). After infusion, 3V lines remained in place, and blood sampling continued for a further $2 \mathrm{~h}$ (total of $6 \mathrm{~h}$ ). Plasma was harvested immediately from samples and frozen at $-20^{\circ} \mathrm{C}$ until assayed.

\section{Experiment 2: effect of lateral ventricular infusion of peptide 271 on $\mathbf{G H}$ in ovariectomized ewes}

Experiments were performed as previously described (Smith et al. 2011). Ewes were bilaterally OVX as above and permanent indwelling lateral ventricle (LV) cannulae were implanted as described previously (Henry et al. 2008). Experimental procedures and blood sampling were similar to above ewes received either peptide 271 ( $1 \mathrm{~h}$ continuous infusion $300 \mu \mathrm{g} / \mathrm{h}$, with an initial $200 \mu \mathrm{g} / \mathrm{h}$ loading dose; $n=5)$ or vehicle (aCSF; $n=5)$ into the LV $(200 \mu \mathrm{g} / \mathrm{h})$. After infusion, LV lines remained in place as blood sampling continued for $3 \mathrm{~h}$. Plasma was harvested immediately and frozen at $-20^{\circ} \mathrm{C}$ until assayed.

\section{Experiment 3: effect of long-term lateral ventricular infusion of peptide 271 on GH in ovary-intact oestrogen-treated anestrous ewes}

Experiments were performed as previously described (Smith et al. 2011), in order to determine the role of kisspeptin signalling in mediating the LH surge; 
hence, a longer infusion period of kisspeptin antagonist was employed. LV and jugular vein cannulae were implanted (as above) in anestrous ewes. All ewes received an initial intramuscular (i.m.) injection of $50 \mu \mathrm{g}$ estradiol benzoate (Intervet, New South Wales, Australia) in $1 \mathrm{~mL}$ peanut oil. Blood sampling commenced $9 \mathrm{~h}$ later and samples $(5 \mathrm{~mL})$ were taken every $10 \mathrm{~min}$ for $9 \mathrm{~h}$, then every $30 \mathrm{~min}$ for a further $12 \mathrm{~h}$. After $3 \mathrm{~h}$ of blood sampling, ewes received $\mathrm{LV}$ infusions $(200 \mu \mathrm{L} / \mathrm{h})$ of kisspeptin antagonist ( $8 \mathrm{~h}$ continuous infusion $300 \mu \mathrm{g} / \mathrm{h}$, with an initial $200 \mu \mathrm{g}$ loading dose; $n=6$ ) or vehicle (aCSF; $n=6$ ). Plasma was harvested immediately and frozen at $-20^{\circ} \mathrm{C}$ until assayed.

\section{Experiment 4: effect of lateral ventricular infusion of kisspeptin-10 on GH secretion in ovary-intact anestrous ewes}

Experiments were performed as previously described (Li et al. 2015), in order to determine the role of kisspeptin in mediating the LH pulses. Ovary-intact ewes during the southern hemisphere anestrus season (September) were prepared for LV and jugular vein cannulation (as above). Blood samples were collected every $10 \mathrm{~min}$ for $3 \mathrm{~h}$, and then animals received kisspeptin $(40 \mu \mathrm{g} / \mathrm{h}$ with an initial loading dose of $40 \mu \mathrm{g}, n=6$ ) or vehicle (aCSF, $n=6)$ treatment for $4 \mathrm{~h}(200 \mu \mathrm{L} / \mathrm{h})$. After the infusion, $\mathrm{LV}$ lines remained in place, and blood sampling continued for a further $2 \mathrm{~h}$ (total of $9 \mathrm{~h}$ ). Plasma was harvested immediately from samples and frozen at $-20^{\circ} \mathrm{C}$ until assayed.

GH radioimmunoassay Plasma samples from ewes were assayed in duplicate following the method of Thomas et al. (1990) using the standard NIDDK-oGH-I-4 and NIDDK-anti-oGH-2 antiserum. The assay sensitivity was $1 \mathrm{ng} / \mathrm{mL}$, the intra-assay CV was less than $10 \%$ between 4 and $51 \mathrm{ng} / \mathrm{mL}$ and the interassay CV was $20 \%$.

\section{Immunocytochemistry of GPR54 and pituitary} hormones in ovine pituitary An antiserum (RM1211) to the carboxyl terminal sequence CVLGEDNAPL of human GPR54 conjugated to haemocyanin was raised in rabbits. The specificity of the highest titre antiserum was demonstrated by positive membrane staining in COS7 cells transfected with the human GPR54 pcDNA and an absence of staining in untransfected COS7 cells (data not shown). Pituitary glands from adult ewes were fixed in Bouin's or $4 \%$ Neutral Buffered formaldehyde (4\%NBF) and sections processed for immunocytochemistry using GPR54 antiserum and counter stained with hematoxylin. To determine which pituitary cell types expressed GPR54, dual staining was conducted with rabbit antisera raised against ovine prolactin, $\mathrm{GH}$, luteinizing hormone and adreno-corticotropic hormone (supplied by the National Hormone and Pituitary Programme of NIDDK). Following dewaxing and rehydration of sections through graded ethanols, endogenous peroxidase activity was blocked using 3\% hydrogen peroxide in methanol, before blocking endogenous biotin using avidin/biotin block (Vector Labs, Peterborough, UK). Sections were then incubated with rabbit anti-GPR5 4 antiserum in 20\% normal goat serum in Tris-buffered saline (TBS). Binding was detected using goat anti-rabbit biotinylated fab (Abcam) and streptavidinHRP before visualising with diaminobenzidine (DAB). Following a repeat of the avidin/blocking, sections were incubated with rabbit antiserum to either porcine ACTH, ovine GH, ovine LH-beta or ovine prolactin at NIDDK recommended dilutions. Binding was detected using secondary biotinylated fab antibody (Abcam) and streptavidin-AP before visualising with fast blue (Abcam).

\section{Data analysis}

All group data are presented as the mean \pm S.E.M. Plasma GH concentrations in response to treatment over time were examined by repeated measures ANOVA. The effect of kisspeptin antagonist or kisspeptin treatment on GH was further examined by comparing the mean GH concentration in samples preinfusion (0-180 min), during the infusion (Experiment 1 and 2, 180-240 min; Experiment 3, 180-720 min; Experiment 4, 180-420 min) and post infusion (Experiment 1, 240-360 min; Experiment 2, 240-420 min; Experiment 3, 720-1260 min; Experiment 4, 420-540 min). The mean GH values were calculated for each animal during the relevant time phase and used to generate group means. Data were assessed by repeated-measures ANOVA.

\section{Results}

\section{Effect of kisspeptin antagonist on GH secretion} in ewes

Third ventricular administration of kisspeptin antagonist peptide-234 significantly increased the plasma concentration of GH in OVX ewes (Fig. 1A). Mean GH was 3 -fold greater during the peptide-234 infusion compared to aCSF control (Fig. 1B, $P<0.005$ ). Table 1 provides a summary of the effects of peptide-234 on GH and our previously published analysis of plasma LH, prolactin and cortisol in ovariectomized ewes (Roseweir et al. 2009). 


\begin{tabular}{l|l|l|c|}
\hline Journal of & J T Smith et al. & Kisspeptin regulation of GH & $\mathbf{2 3 7 : 2}$ \\
Endocrinology & & $\mathbf{1 6 8}$
\end{tabular}
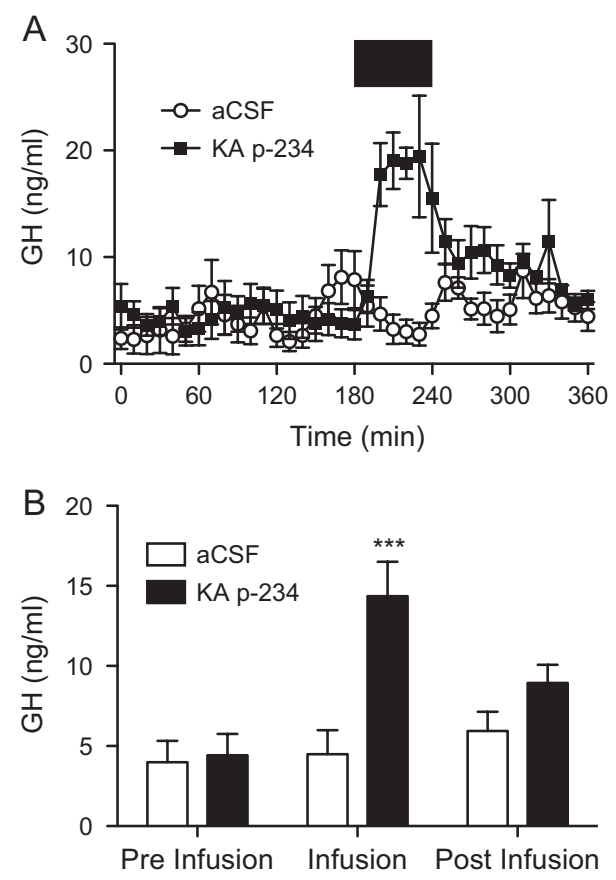

Figure 1

Third ventricle infusion of kisspeptin antagonist (KA p-234) stimulated the secretion of GH in OVX ewes. (A) Mean concentrations of GH are shown in ewes treated with kisspeptin antagonist (closed squares) or aCSF (open circles). The infusion period is represented by the closed bar. (B) Mean GH before, during and after infusion ( $n=4$ per group). A significantly elevated mean GH concentration during kisspeptin antagonist infusion was detected. Data are the mean \pm S. E.M. $* * * P<0.001$. $P<0.05$ was considered significant.

Lateral ventricular administration of peptide-271 resulted in similar effects (Fig. 2A). Mean GH levels (Fig. 2B) were again significantly elevated during the time of the antagonist infusion compared to vehicle controls $(P<0.01)$. Previously, peptide-271 inhibited LH pulses and mean LH in ovariectomized ewes (Smith et al. 2011).

Similar results were achieved with central peptide-271 treatment in ovary-intact ewes (Fig. 3A). Here, the mean GH concentration over the 8-h continuous peptide-271 infusion was significantly greater than that during the aCSF infusion $(P<0.001$, Fig. 3B). From our previous analysis, the peptide-271 kisspeptin antagonist in this paradigm significantly attenuated the estradiol-induced LH surge (Smith et al. 2011).

\section{Effect of kisspeptin-10 on GH secretion in ovary- intact anestrous ewes}

Lateral ventricular administration of kisspeptin-10 had no effect on plasma GH concentrations in ovary-intact anestrous ewes (Fig. 4A). Mean GH concentration over the 4 -h continuous infusion period was similar between
Table 1 Summary of plasma GH, LH, prolactin and cortisol from Experiment 1.

\begin{tabular}{|c|c|c|c|}
\hline & Control & Peptide-234 & $P$ value \\
\hline \multicolumn{4}{|l|}{ Mean GH (ng/mL) } \\
\hline Pre infusion & $3.99 \pm 1.33$ & $4.42 \pm 1.33$ & 0.84 \\
\hline Infusion & $4.49 \pm 1.49$ & $14.36 \pm 2.15$ & $<0.005$ \\
\hline Post infusion & $5.93 \pm 1.20$ & $8.94 \pm 1.13$ & 0.11 \\
\hline \multicolumn{4}{|c|}{ Mean LH (ng/mL)* } \\
\hline Pre infusion & $2.70 \pm 0.34$ & $2.73 \pm 0.43$ & 0.96 \\
\hline Infusion & $2.44 \pm 0.25$ & $2.89 \pm 0.55$ & 0.50 \\
\hline Post infusion & $2.60 \pm 0.11$ & $1.78 \pm 0.34$ & $<0.05$ \\
\hline \multicolumn{4}{|c|}{ Mean prolactin $(\mathrm{ng} / \mathrm{mL})$ * } \\
\hline Pre infusion & $27.89 \pm 9.21$ & $58.67 \pm 14.59$ & 0.12 \\
\hline Infusion & $17.02 \pm 7.34$ & $44.91 \pm 15.87$ & 0.16 \\
\hline Post infusion & $5.58 \pm 3.23$ & $27.74 \pm 9.23$ & 0.06 \\
\hline \multicolumn{4}{|c|}{ Mean cortisol $(\mathrm{ng} / \mathrm{mL})$ * } \\
\hline Pre infusion & $11.90 \pm 2.79$ & $8.08 \pm 1.96$ & 0.31 \\
\hline Infusion & $8.51 \pm 1.81$ & $8.26 \pm 1.55$ & 0.92 \\
\hline Post infusion & $11.57 \pm 2.00$ & $18.45 \pm 5.98$ & 0.32 \\
\hline
\end{tabular}

*Data derived from experiments in Roseweir et al. (2009).

kisspeptin-10 and control ewes (Fig. 4B). In the same animals, there was a significant stimulation of $\mathrm{LH}(\mathrm{Li}$ et al. 2015).

\section{Ovine somatotropes co-express kisspeptin receptor}

Pituitaries from adult ewes displayed clear immunostaining with the GPR54 antiserum RM 1211 in both NBF (Fig. 5E) and Bouins (Fig. 5F) fixation. Staining was ablated by preincubation of the antiserum with the CVLGEDNAPL immunogen (data not shown). Subsequent staining with rabbit antisera to prolactin, adreno-corticotropin, luteinizing hormone and GH in Bouins clearly revealed the various cell types but staining of some of these hormones was not clear with NBF staining (data not shown). In the Bouins fixed tissue, there was little or no co-localisation of staining $(<1 \%)$ in corticotropes (Fig. $5 \mathrm{~A})$, gonadotropes (Fig. 5C) and lactotropes ( $<1 \%$, Fig. 5D), while the majority of somatotropes (86\%, Fig. 5B) stained positive for GPR54.

\section{Discussion}

Adequate GH secretion is required for optimal reproductive hormone production during puberty and in adulthood. Because GH is involved in metabolic regulation and recent evidence supports the concept that kisspeptin is an integrator of nutrition and metabolic regulation of reproduction (Pineda et al. 2010a, De Bond \& Smith 2014), it is plausible that kisspeptin may 

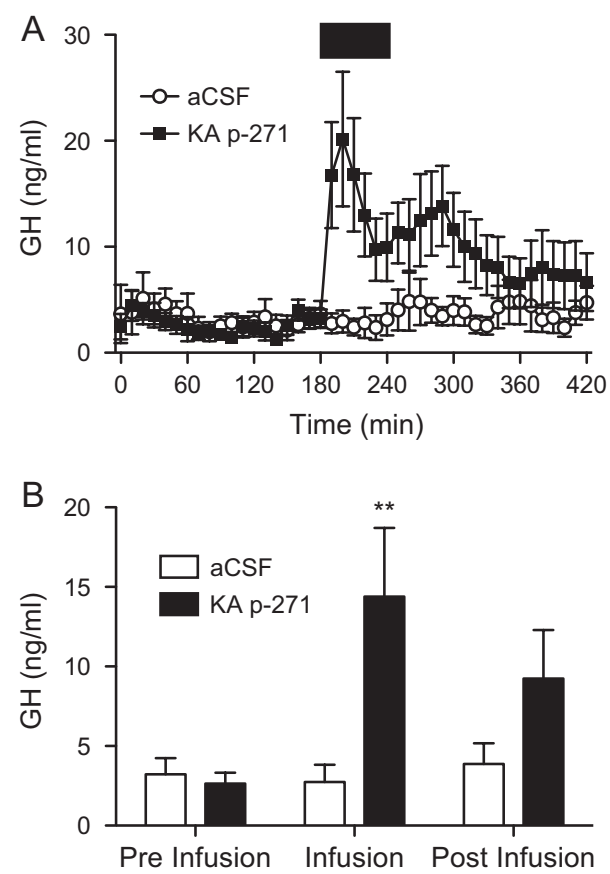

\section{Figure 2}

Lateral ventricle infusion of kisspeptin antagonist (KA p-271) stimulated the secretion of GH in OVX ewes. (A) Mean concentrations of GH are shown in ewes treated with kisspeptin antagonist (closed squares) or aCSF (open circles). The infusion period is represented by the closed bar. (B) Mean GH before, during and after infusion ( $n=5$ per group). A significantly elevated mean $\mathrm{GH}$ concentration during kisspeptin antagonist infusion was detected. Data are the mean \pm S.E.M. $* * P<0.01$. $P<0.05$ was considered significant.

be a regulator of GH. A number of publications support this notion. Kisspeptin stimulated calcium influx in rat somatrotropes and secretion of GH from rat (GutierrezPascual et al. 2007) and bovine (Kadokawa et al. 2007) pituitary cells. However, Jayasena et al. (2014) found no effect of kisspeptin on GH secretion from the pituitary in vitro. In vivo studies present a complexity of findings including contradictory reports. High i.v. doses $(>3 \mathrm{nmol} / \mathrm{kg}$ ) of kisspeptin stimulated prolonged $\mathrm{GH}$ release in prepubertal heifers (Kadokawa et al. 2008) but a lower dose of kisspeptin had no effect in ovariectomised adult cows but stimulated GH when progesterone or oestrogen or both were administered (Whitlock et al. 2008). Central or systemic administration of kisspeptin had no effect on GH in prepubertal female pigs while inducing LH secretion (Lents et al. 2008). Similarly kisspeptin peripheral infusion had no effect on GH in cows while robustly stimulating LH but preinfusion of kisspeptin reduced GH responses to GHRH and somatostatin withdrawal (Whitlock et al. 2010). This study also reported no GH response to i.v. kisspeptin in ewes but a small response when administered i.c.v. (Whitlock et al. 2010).
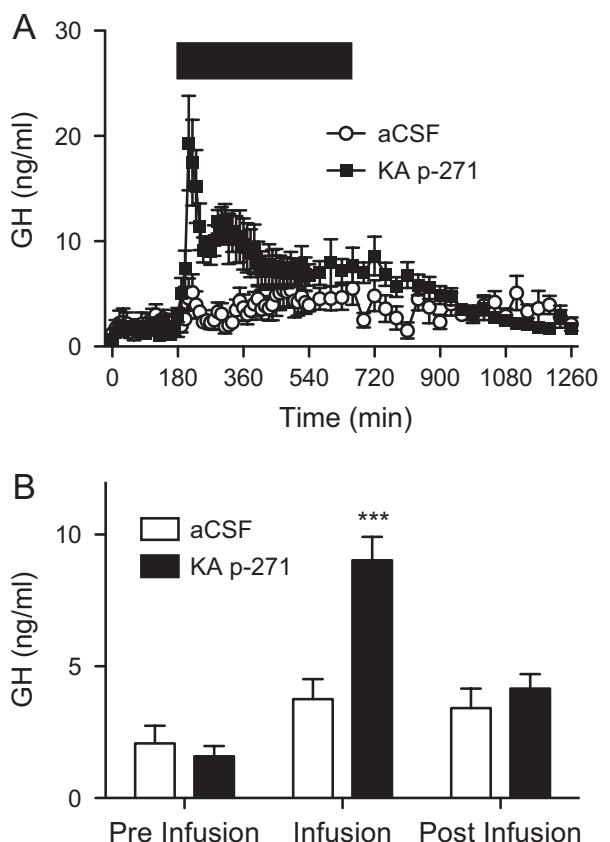

Figure 3

Long-term $(8 \mathrm{~h})$ lateral ventricle infusion of kisspeptin antagonist (KA $\mathrm{p}$-271) stimulated the secretion of GH in intact anestrus ewes. (A) Mean concentrations of $\mathrm{GH}$ are shown in ewes treated with kisspeptin antagonist (closed squares) or aCSF (open circles). The infusion period is represented by the closed bar. (B) Mean GH before, during and after infusion ( $n=6$ per group). A significantly elevated mean $\mathrm{GH}$ concentration during kisspeptin antagonist infusion was detected. Data are the mean \pm S.E.M. $* * * P<0.001 . P<0.05$ was considered significant.

However, recently published data show kisspeptin can stimulate GH, but only in fasted ewes, by a ghrelin-NPYmediated mechanism (Foradori et al.2017). These complex, and often, contradictory reports may be a result of the large family of RFamide receptors, which can be targeted by kisspeptin. We attempted to clarify the field by utilising specific antagonists to GPR54. In our study, we found no effect of administration of kisspeptin into the $\mathrm{LV}$ on GH secretion in intact ewes, which is in agreement with the reported lack of response to peripheral administration in intact cows studies (Whitlock et al. 2008) and prepubertal female pigs (Lents et al. 2008) but contrasts with a small GH increase reported in ewes (Whitlock et al. 2010) although the immediate nutritional status may be key in this model (Foradori et al. 2017). In women, both acute and chronic peripheral administration of kisspeptin-54 failed to alter GH concentrations (Jayasena et al. 2014). As mentioned above, these varying and contradictory reports on the effects of kisspeptin on GH may be the result of cross signalling through the large family of RFamide receptors, especially when high doses are administered centrally. For example, we have observed that kisspeptin has a 

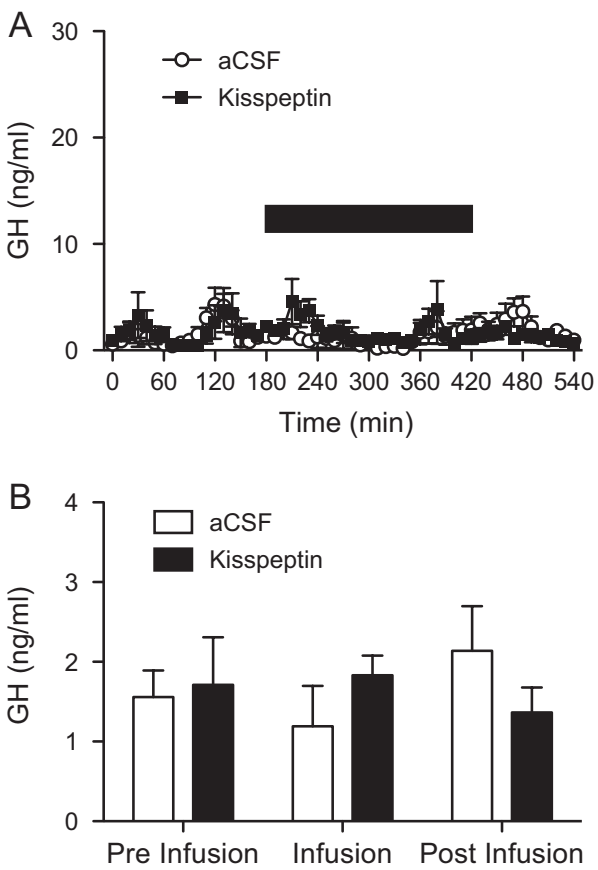

Figure 4

Central infusion of kisspeptin had no effect on secretory pulses of GH in ewes. (A) Concentrations of $\mathrm{GH}$ are shown in ewes treated with kisspeptin or aCSF (vehicle). The infusion period is represented by the closed bar. (B) Mean GH before, during and after infusion ( $n=6$ per group). Data are mean \pm S.E.M. $P<0.05$ was considered significant.

high affinity for the GnIH receptor, GPR147, while GnIH binds poorly to GPR54 (Millar RP, unpublished data). In the same study, peptide-234 and peptide-271 did not bind to GPR147 suggesting that they do not interact with other RFamide receptors and are better probes for determining the role of kisspeptin in GH secretion.

We have therefore attempted to reconcile these apparently conflicting effects of kisspeptin on GH by administering kisspeptin antagonists in ovariectomised and oestrogen-treated anestrous ewes. Robust increases in GH were observed in three separate and different experiments after administration of either antagonist peptide-234 or antagonist peptide-271. Moreover, GH was increased regardless of site of administration ( $3 \mathrm{~V}$ or LV) and the nature of the antagonist: peptide-271, which has the penetratin sequence attached at the $\mathrm{NH} 2$ terminus, designed to be cell-permeant or non-cell-permeant peptide-234). For each experiment, ovariectomy or estradiol treatment increased LH pulse and surge dynamics (respectively) and kisspeptin antagonist inhibited plasma LH concentrations but had no effect on cortisol or prolactin (Roseweir et al. 2009, Smith et al. 2011). Thus, the effects are highly specific for GH increase and LH decrease without affecting other pituitary hormones
(Table 1). The timing of each effect (GH vs LH) appears, however, to differ, with the relatively delayed effect on LH being due to a time delay in the antagonists having first to compete out endogenous kisspeptin, which then results in a decrease in GnRH followed by a decrease in LH. In contrast, the effect on GH appears much more acute, possibly due to the more direct and immediate effect on the pituitary somatotrope expressing GPR54 receptors.

The stimulation of $\mathrm{GH}$ by both kisspeptin antagonists suggests that endogenous kisspeptin is restraining GH secretion in the ewe models we studied. This might be at a hypothalamic level through inhibiting GHRH or stimulating somatostatin as suggested by Whitlock et al. (2010) or directly at the pituitary level on somotatropes or through other pituitary cell types that affect the somatotrope. To address the site of kisspeptin action, we examined the expression of GPR54 in ewe pituitary cell types using a highly specific antiserum to GPR54. GPR54 was almost exclusively expressed in somatotropes and was virtually absent in LH-positive gonadotropes, prolactinpositive lactotropes or ACTH-positive corticotropes. This expression of GPR54 on somatotropes therefore provides a potential mechanism for the kisspeptin and antagonist effects on GH. GPR54 mRNA expression has been previously reported in dispersed sheep pituitary mainly in somatotropes, with lower expression in enriched lactotropes and gonadotropes (Smith et al. 2008) but GPR54 protein was not examined as in this study, which showed expression of protein predominantly in somatotropes.

The sources of kisspeptin, which may target GPR54 in somatotropes, are potentially through hypothalamic kisspeptin secretion into the portal system or from peripheral tissues via the systemic circulation or through local pituitary cell production. Systemic and portal sources are unlikely because kisspeptin in hypophyseal portal blood in ewes (which is the sum of hypothalamic secretion and systemic levels) is very low with a maximum of $12 \mathrm{pg} / \mathrm{mL}$ (Smith et al. 2008). This equates to about $10 \mathrm{pM}$ for $\mathrm{Kp}-10$ and $2 \mathrm{pM}$ for $\mathrm{Kp}-54$. This level is too low for effective receptor occupancy as the affinity (i.e. 50\% receptor occupancy) of GPR54 for kisspeptin is about 1-5 nM (Roseweir et al. 2009) - about 1000 times higher. This indicates that GH stimulation is not from hypothalamic kisspeptin targeting somatotropes via the portal system or from the general circulation. Expression of kisspeptin has been reported in the pituitary gland of mammalian species (Kotani et al. 2001, Muir et al. 2001, Gutierrez-Pascual et al. 2007, Richard et al. 2008, Quennell et al. 2010) and in some instances localised to specific 

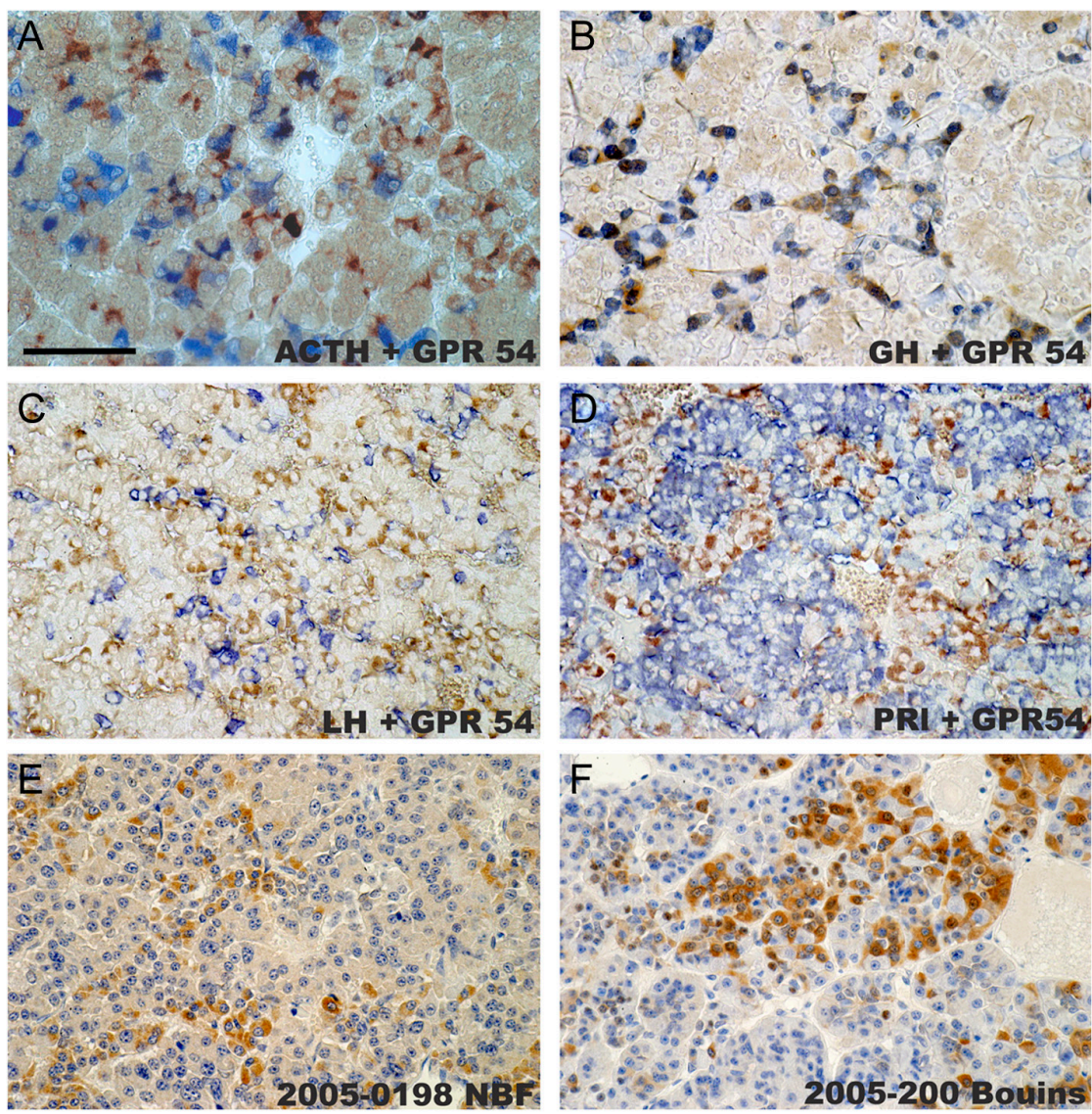

\section{Figure 5}

Representative photomicrographs showing immunohistochemical localization of GPR54 (brown) in the adult ewe pituitary. Immunostaining with rabbit antisera to adreno-corticotropin (A, ACTH + GPR54), growth hormone (B, GH + GPR54), luteinizing hormone (C, LH + GPR54) and prolactin (D, PRI + GPR54) revealed the various cell types (blue). The majority of somatotropes ( $86 \%$ ) stained positive for GPR54 (B). (E and F) Show GPR54 staining in pituitary sections fixed with $4 \%$ neutral buffered formaldehyde (E; 205-0198 NBF) or Bouins (F; 2005-200 Bouins) and counter stained with hematoxylin (blue). Scale bar, $100 \mu \mathrm{m}$. pituitary cell types such as corticotropes in the rhesus monkey (Ramaswamy et al. 2009), gonadotropes in the rat (Richard et al. 2008) and to enriched somotatropes, lactotropes and gonadotropes in ewes (Smith et al. 2008). This therefore suggests that local pituitary kisspeptin production inhibits somatotrope secretion of $\mathrm{GH}$, which is ablated by the antagonists to increase GH.

The demonstration in this study of a virtual absence of GPR54 in gonadotropes in the ewe indicates that previous reports on kisspeptin stimulation of LH secretion from the ewe pituitary in vitro (Smith et al. 2008) are unlikely to be mediated via GPR54 in gonadotropes and are most likely to be indirectly through somatotropes or nonspecific on related RFamine receptors. Importantly, the effect of kisspeptin and/or kisspeptin antagonists on GH release from sheep pituitary primary cultures or cultured somatotropes has not (to our knowledge) been studied. Our demonstration of high expression of GPR54 in somatotropes suggests a possibility that they might secrete activators of gonadotropes to account for the observation of kisspeptin stimulation of LH in the pituitary. It is also feasible that since relatively high doses of kisspeptin were required to stimulate $\mathrm{LH}$ from the pituitary in the studies by Witham et al. (2013) (100 nM) and Gutierrez-Pascual et al. (2007) (10-100 nM), the effect may be through kisspeptin activation of other RFamide receptors. Studies using kisspeptin antagonists may clarify this. However, the demonstration that kisspeptin at doses that stimulate LH in intact ewes do not stimulate LH when administered to hypothalamic-pituitary-disconnected ewes (Smith et al. 2008) suggests that although kisspeptin can stimulate LH secretion from the pituitary in vitro it does not play a significant role in the direct stimulation of the gonadotrope in the ewe in vivo.

In summary, we have demonstrated that two kisspeptin antagonists administered into the $\mathrm{LV}$ or $3 \mathrm{~V}$ robustly stimulate $\mathrm{GH}$ in ovariectomised and oestrogentreated anestrous ewes. The kisspeptin receptor GPR54 is expressed in the majority of somatotropes suggesting that endogenous kisspeptin binds to these receptors and inhibits $\mathrm{GH}$ secretion such that kisspeptin antagonists elevate growth hormone. These findings lay the foundation for more in depth study on the precise physiological relationships between the reproductive and GH systems and the possibility of developing kisspeptin antagonists as therapeutics for GH stimulation. 


\section{Declaration of interest}

The authors declare that there is no conflict of interest that could be perceived as prejudicing the impartiality of the research reported.

\section{Funding}

This work did not receive any specific grant from any funding agency in the public, commercial, or not-for-profit sector.

\section{Author contribution statement}

J T S, I J C and R P M contributed to the conception and design of the research; J T S, A R, M M and R P M performed the experiments, analysed the data and interpreted the results of the experiments; J T S and R P M drafted the manuscript; J T S, I J C and R P M edited and revised the manuscript; J T S, A R, M M, I J C and R P M approved the final version of the manuscript.

\section{References}

Albers-Wolthers CHJ, de Gier J, Walen M, van Kooten PJS, Lambalk CB, Leegwater PAJ, Roelen BAJ, Schaefers-Okkens AC, Rutten V, Millar RPM, et al. 2017 In vitro and in vivo effects of kisspeptin antagonists p234, p271, p354, and p356 on GPR54 activation. PLoS ONE 12 e0179156. (https://doi.org/10.1371/journal.pone.0179156)

Barker-Gibb ML, Scott CJ, Boublik JH \& Clarke IJ 1995 The role of neuropeptide Y (NPY) in the control of LH secretion in the ewe with respect to season, NPY receptor subtype and the site of action in the hypothalamus. European Journal of Endocrinology 147 565-579. (https://doi.org/10.1677/joe.0.1470565)

De Bond JA \& Smith JT 2014 Kisspeptin and energy balance in reproduction. Reproduction 147 R53-R63. (https://doi.org/10.1530/ REP-13-0509)

De Bond JA, Li Q, Millar RP, Clarke IJ \& Smith JT 2013 Kisspeptin signaling is required for the luteinizing hormone response in anestrous ewes following the introduction of males. PLOS ONE 8 e57972. (https://doi.org/10.1371/journal.pone.0057972)

de Roux N, Genin E, Carel JC, Matsuda F, Chaussain JL \& Milgrom E 2003 Hypogonadotropic hypogonadism due to loss of function of the KiSS1-derived peptide receptor GPR54. PNAS 100 10972-10976. (https://doi.org/10.1073/pnas.1834399100)

Dockray GJ 2004 The expanding family of -RFamide peptides and their effects on feeding behaviour. Experimental Physiology 89 229-235. (https://doi.org/10.1113/expphysiol.2004.027169)

Foradori CD, Whitlock BK, Daniel JA, Zimmerman AD, Jones MA, Read CC, Steele BP, Smith JT, Clarke IJ, Elsasser TH, et al. 2017 Kisspeptin stimulates growth hormone release by utilizing neuropeptide $\mathrm{Y}$ pathways and is dependent on the presence of ghrelin in the ewe. Endocrinology 158 3526-3539. (https://doi.org/10.1210/ en.2017-00303)

Gottsch ML, Cunningham MJ, Smith JT, Popa SM, Acohido BV, Crowley WF, Seminara S, Clifton DK \& Steiner RA 2004 A role for kisspeptins in the regulation of gonadotropin secretion in the mouse. Endocrinology 145 4073-4077. (https://doi.org/10.1210/ en.2004-0431)

Guerriero KA, Keen KL, Millar RP, Terasawa E Millar RP \& Terasawa E 2012 Developmental changes in GnRH release in response to kisspeptin agonist and antagonist in female rhesus monkeys (Macaca mulatta): implication for the mechanism of puberty. Endocrinology 153 825-836. (https://doi.org/10.1210/en.2011-1565)
Gutierrez-Pascual E, Martinez-Fuentes AJ, Pinilla L, Tena-Sempere M, Malagon MM \& Castano JP 2007 Direct pituitary effects of kisspeptin: activation of gonadotrophs and somatotrophs and stimulation of luteinising hormone and growth hormone secretion. Journal of Neuroendocrinology 19 521-530. (https://doi.org/10.1111/j.13652826.2007.01558.x)

Han SK, Gottsch ML, Lee KJ, Popa SM, Smith JT, Jakawich SK, Clifton DK, Steiner RA \& Herbison AE 2005 Activation of gonadotropin-releasing hormone neurons by kisspeptin as a neuroendocrine switch for the onset of puberty. Journal of Neuroscience 25 11349-11356. (https://doi. org/10.1523/JNEUROSCI.3328-05.2005)

Henry BA, Dunshea FR, Gould M \& Clarke IJ 2008 Profiling postprandial thermogenesis in muscle and fat of sheep and the central effect of leptin administration. Endocrinology 149 2019-2026. (https://doi. org/10.1210/en.2007-1311)

Hull KL \& Harvey S 2001 Growth hormone: roles in female reproduction. Journal of Endocrinology 168 1-23. (https://doi.org/10.1677/ joe.0.1680001)

Hull KL \& Harvey S 2002 GH as a co-gonadotropin: the relevance of correlative changes in $\mathrm{GH}$ secretion and reproductive state. Journal of Endocrinology 172 1-19. (https://doi.org/10.1677/joe.0.1720001)

Jayasena CN, Comninos AN, Narayanaswamy S, Bhalla S, Abbara A, Ganiyu-Dada Z, Busbridge M, Ghatei MA, Bloom SR \& Dhillo WS 2014 Acute and chronic effects of kisspeptin-54 administration on $\mathrm{GH}$, prolactin and TSH secretion in healthy women. Journal of Clinical Endocrinology 81 891-898. (https://doi.org/10.1111/cen.12512)

Kadokawa H, Suzuki S \& Hashizume T 2007 Kisspeptin-10 stimulates the secretion of growth hormone and prolactin directly from cultured bovine anterior pituitary cells. Animal Reproduction Science $\mathbf{1 0 5}$ 404-408. (https://doi.org/10.1016/j.anireprosci.2007.11.005)

Kadokawa H, Matsui M, Hayashi K, Matsunaga N, Kawashima C, Shimizu T, Kida K \& Miyamoto A 2008 Peripheral administration of kisspeptin-10 increases plasma concentrations of growth hormone as well as luteinizing hormone in prepubertal Holstein heifers. Journal of Endocrinology 196 331-334. (https://doi.org/10.1677/JOE-07-0504)

Kotani M, Detheux M, Vandenbogaerde A, Communi D, Vanderwinden JM, Le Poul E, Brezillon S, Tyldesley R, SuarezHuerta N, Vandeput F, et al. 2001 The metastasis suppressor gene KiSS-1 encodes kisspeptins, the natural ligands of the orphan G protein-coupled receptor GPR54. Journal of Biological Chemistry $\mathbf{2 7 6}$ 34631-34636. (https://doi.org/10.1074/jbc.M104847200)

Lents CA, Heidorn NL, Barb CR \& Ford JJ 2008 Central and peripheral administration of kisspeptin activates gonadotropin but not somatotropin secretion in prepubertal gilts. Reproduction $\mathbf{1 3 5}$ 879-887. (https://doi.org/10.1530/REP-07-0502)

Li Q, Millar RP, Clarke IJ \& Smith JT 2015 Evidence that neurokinin B controls basal gonadotropin-releasing hormone secretion but is not critical for estrogen-positive feedback in sheep. Neuroendocrinology 101 161-174. (https://doi.org/10.1159/000377702)

Millar RP, Roseweir AK, Tello JA, Anderson RA, George JT, Morgan K \& Pawson AJ 2010 Kisspeptin antagonists: unraveling the role of kisspeptin in reproductive physiology. Brain Research 1364 81-89. (https://doi.org/10.1016/j.brainres.2010.09.044)

Muir AI, Chamberlain L, Elshourbagy NA, Michalovich D, Moore DJ, Calamari A, Szekeres PG, Sarau HM, Chambers JK, Murdock P, et al. 2001 AXOR12, a novel human G protein-coupled receptor, activated by the peptide KiSS-1. Journal of Biological Chemistry $\mathbf{2 7 6}$ 28969-28975. (https://doi.org/10.1074/jbc.M102743200)

Oishi S, Misu R, Tomita K, Setsuda S, Masuda R, Ohno H, Naniwa Y, Ieda N, Inoue N, Ohkura S, et al. 2011 Activation of neuropeptide FF receptors by kisspeptin receptor ligands. ACS Medicinal Chemistry Letters 2 53-57. (https://doi.org/10.1021/ml1002053)

Pineda R, Aguilar E, Pinilla L \& Tena-Sempere M 2010a Physiological roles of the kisspeptin/GPR54 system in the neuroendocrine control of reproduction. Progress in Brain Research 181 55-77. (https://doi. org/10.1016/S0079-6123(08)81005-9) 
Pineda R, Garcia-Galiano D, Roseweir A, Romero M, Sanchez-Garrido MA, Ruiz-Pino F, Morgan K, Pinilla L, Millar RP \& Tena-Sempere M $2010 b$ Critical roles of kisspeptins in female puberty and preovulatory gonadotropin surges as revealed by a novel antagonist. Endocrinology 151 722-730. (https://doi.org/10.1210/en.2009-0803)

Quennell JH, Rizwan MZ, Relf HL \& Anderson GM 2010 Developmental and steroidogenic effects on the gene expression of RFRP and its receptor in the rat brain and pituitary gland. Journal of Neuroendocrinology 22 309-316. (https://doi.org/10.1111/j.13652826.2010.01963.x)

Ramaswamy S, Gibbs RB \& Plant TM 2009 Studies of the localisation of kisspeptin within the pituitary of the rhesus monkey (Macaca mulatta) and the effect of kisspeptin on the release of nongonadotropic pituitary hormones. Journal of Neuroendocrinology $2 \mathbf{1}$ 795-804. (https://doi.org/10.1111/j.1365-2826.2009.01905.x)

Richard N, Galmiche G, Corvaisier S, Caraty A \& Kottler ML 2008 KiSS-1 and GPR54 genes are co-expressed in rat gonadotrophs and differentially regulated in vivo by oestradiol and gonadotrophinreleasing hormone. Journal of Neuroendocrinology 20 381-393. (https:// doi.org/10.1111/j.1365-2826.2008.01653.x)

Roseweir AK \& Millar RP 2013 Kisspeptin antagonists. Advances in Experimental Medicine and Biology 784 159-186. (https://doi. org/10.1007/978-1-4614-6199-9_8)

Roseweir AK, Kauffman AS, Smith JT, Guerriero KA, Morgan K, Pielecka-Fortuna J, Pineda R, Gottsch ML, Tena-Sempere M, Moenter SM, et al. 2009 Discovery of potent kisspeptin antagonists delineate physiological mechanisms of gonadotropin regulation. Journal of Neuroscience 29 3920-3929. (https://doi.org/10.1523/ JNEUROSCI.5740-08.2009)

Seminara SB, Messager S, Chatzidaki EE, Thresher RR, Acierno JS Jr, Shagoury JK, Bo-Abbas Y, Kuohung W, Schwinof KM, Hendrick AG, et al. 2003 The GPR54 gene as a regulator of puberty. New England Journal of Medicine 349 1614-1627. (https://doi.org/10.1056/ NEJMoa035322)
Smith JT 2013 Sex steroid regulation of kisspeptin circuits. Advances in Experimental Medicine and Biology 784 275-295. (https://doi. org/10.1007/978-1-4614-6199-9_13)

Smith JT, Rao A, Pereira A, Caraty A, Millar RP \& Clarke IJ 2008 Kisspeptin is present in ovine hypophysial portal blood but does not increase during the preovulatory luteinizing hormone surge: evidence that gonadotropes are not direct targets of kisspeptin in vivo. Endocrinology 149 1951-1959. (https://doi.org/10.1210/en.2007-1425)

Smith JT, Li Q, Yap KS, Shahab M, Roseweir AK, Millar RP \& Clarke IJ 2011 Kisspeptin is essential for the full preovulatory LH surge and stimulates $\mathrm{GnRH}$ release from the isolated ovine median eminence. Endocrinology 152 1001-1012. (https://doi.org/10.1210/en.2010-1225)

Thomas GB, Mercer JE, Karalis T, Rao A, Cummins JT \& Clarke IJ 1990 Effect of restricted feeding on the concentrations of growth hormone $(\mathrm{GH})$, gonadotropins, and prolactin (PRL) in plasma, and on the amounts of messenger ribonucleic acid for GH, gonadotropin subunits, and PRL in the pituitary glands of adult ovariectomized ewes. Endocrinology $\mathbf{1 2 6}$ 1361-1367. (https://doi.org/10.1210/endo-126-3-1361)

Topaloglu AK, Tello JA, Kotan LD, Ozbek MN, Yilmaz MB, Erdogan S, Gurbuz F, Temiz F, Millar RP \& Yuksel B 2012 Inactivating KISS1 mutation and hypogonadotropic hypogonadism. New England Journal of Medicine 366 629-635. (https://doi.org/10.1056/NEJMoa1111184)

Whitlock BK, Daniel JA, Wilborn RR, Rodning SP, Maxwell HS, Steele BP \& Sartin JL 2008 Interaction of estrogen and progesterone on kisspeptin-10-stimulated luteinizing hormone and growth hormone in ovariectomized cows. Neuroendocrinology 88 212-215. (https://doi. org/10.1159/000146242)

Whitlock BK, Daniel JA, Wilborn RR, Maxwell HS, Steele BP \& Sartin JL 2010 Interaction of kisspeptin and the somatotropic axis. Neuroendocrinology 92 178-188. (https://doi.org/10.1159/000318049)

Witham EA, Meadows JD, Hoffmann HM, Shojaei S, Coss D, Kauffman AS \& Mellon PL 2013 Kisspeptin regulates gonadotropin genes via immediate early gene induction in pituitary gonadotropes. Molecular Endocrinology 27 1283-1294. (https://doi.org/10.1210/me.2012-1405)

Received in final form 6 March 2018

Accepted 15 March 2018

Accepted Preprint published online 16 March 2018 